\title{
Crown Efficiency and Pine Cones Production for Brazilian Pine (Araucaria angustifolia (Bertol.) Kuntze) in South Brazil
}

\author{
André Felipe Hess ${ }^{1}$, Kemely Alves Atanazio ${ }^{1}$, Geedre Adriano Borsoi ${ }^{1}$, Luis Paulo Baldissera Schorr ${ }^{1}$, \\ Isadora de Arruda Souza ${ }^{1}$, Emanuel Arnoni Costa $^{1}$, Danieli Regina Klein ${ }^{1}$, Sandra Mara Krefta ${ }^{1}$, \\ Thiago Floriani Stepka ${ }^{1}$, Roberta Abatti ${ }^{1}$, Polliny Ricken ${ }^{2} \&$ Gabriel Teixeira da Rosa ${ }^{1}$ \\ ${ }^{1}$ Department of Forest Engineering, State University of Santa Catarina, Brazil \\ ${ }^{2}$ Department of Forest Engineering, Federal University of Paraná, Brazil \\ Correspondence: André Felipe Hess, Department of Forest Engineering, State University of Santa Catarina, \\ Brazil. Luiz de Camoes, Ave. 2090, 88520-000, Lages, Santa Catarina, Brazil. E-mail: hessandre@yahoo.com.br
}

Received: February 9, 2019

Accepted: March 13, 2019 Online Published: May 15, 2019

doi:10.5539/jas.v11n6p247

URL: https://doi.org/10.5539/jas.v11n6p247

\begin{abstract}
Crown efficiency is a relation of growth with the area tree occupies (available area efficiency). Efficiency is associated with the vertical and lateral expansion capacity of the tree and crown, increase, density and light absorption. Thus, our study aimed to evaluate crown efficiency with pine cones tree ${ }^{-1}$ production and dendro/morphometric variables of individual araucaria trees in three forest sites in south Brazil. In each site of each tree, dendrometric and morphometric variables were measured and increment rolls were taken at the breast height diameter level. Together with these data, the morphometric indexes, annual periodic increment in diameter of the last ten years $\left(\mathrm{API}_{\mathrm{d}}\right)$ and efficiency of the crown as a function of API $\mathrm{d}_{\mathrm{d}}$ by the horizontal projection area of the crown (hpac) and number of pine cones tree ${ }^{-1}(\mathrm{np})$ by hpac were calculated. Crown efficiency was modeled as a function of the independent variables hpac, API $_{d}$, crown length (cl), crown ratio (cr) and np. The accuracy of the adjustment was evaluated by the statistics of the deviance, Akaike's information criterion and graph of the residuals. The results show that the number of pine cones tree ${ }^{-1}$ increases with annual periodic increment in diameter and diameter. Crown efficiency decreases with increasing hpac, $\mathrm{cl}$ and cr, indicating silvicultural treatments should be performed with the removal of trees of larger diameter and crown size. A higher pine cones production and efficiency correlates with forest growth, shape, competition, sociological position (stratum tree occupies) and density.
\end{abstract}

Keywords: growth, tree morphometry, forest mensuration, tree morphology

\section{Introduction}

Araucaria or Brazilian pine (Araucaria angustifolia (Bertol.) Kuntze) is a dioecious species characteristic of the mixed ombrophilous forest in south Brazil. It is of extreme importance due to the commercial value of its wood and edible seeds with pine cones production (Figures 2C and 2D). However, silvicultural treatments and sustainable management for the use of wood are prohibited by law, being only the exploitation of its pine cones allowed. Their amount (pine cones and edible seeds) depends on tree age, crown size, light, density, crown efficiency, growth, availability and dispersal of pollen from tree males.

The energy source of a tree is sunlight, which is transformed into chemical energy by the process of photosynthesis (Sanqueta et al., 2014). The organ responsible for this process is the crown. Thus, variables such as surface of the crown, diameter and crown length are directly related to growth and production (wood and non-wood) of trees.

Productivity per unit area refers to crown shape. Multi-level crowns with a central trunk produce more per unit area than large hemispherical crowns with many branches and only one level (Wadsworth, 2000). The same author pointed out that the crown size and shapes influence productivity. Trees of the upper canopy have horizontal and less dense crowns; those in the lower stratum have vertical and deep crowns. Some authors such as Burger (1939) and Assmann (1961) were the pioneers in conducting studies on the shapes, dimensions and morphometric relationships for crowns. 
Assmann (1970), Sterba et al. (1993), Reid et al. (2004), and Gspaltl et al. (2012) reported crown efficiency as the ratio between volume increment/basal area with the horizontal projection area of the crown. Thus, according to this definition, by knowing the least efficient trees it is possible to determine their removal during thinning (Sterba \& Amateis, 1998), and define the trees that must be left in order to reach the maximum efficiency of growth space and consequently growth volume per hectare, i.e. inferred in the growth forecast in response to various silvicultural treatments (Waring et al., 1981; O’hara, 1988).

For the present study, an adaptation of the efficiency model was used, referring to as a ratio between the number of pine cones per trees as a function of the horizontal projection area of the crown and its adjustment in function of the annual periodic increment in diameter, diameter and morphometric variables. The justification for this adaptation was to solve the studied problem in Araucaria Forest: the decrease in pine cones production in recent years. So far, studies that associate crown efficiency with pine cones production are still incipient in the region.

Different types of interactions can be studied using crown efficiency. These are important because, according to Silveira et al. (2018), Hess et al. (2018), and Costa et al. (2018) Araucaria forests remnants show stagnant growth rates, competition, low natural regeneration rate, higher mortality rates than ingrowth (Becker et al., 2014). Impaired future diameter structure, irregular crown formation, associated with lack of forest management (4 decades without silvicultural treatment) which may be the main reason for the current problem of pine cones production.

We believe the tree crown size is a key variable in this context as it correlates with the space a tree occupies as well as with the physiological tree functions mentioned above. For instance, crown projection area and crown volume can be used as proxy variables for leaf area and leaf biomass (Binkley et al., 2013; Forrester, 2013).

In contrast, tree crown and tree stem diameter growth are very sensitive to competition (Pretzsch et al., 2015). According to these authors, based on vertical and lateral crown expansion (height, height to crown base, crown diameter) many tree characteristics, functions, and services can be derived. Thus, one of the hypotheses studied here is that crown efficiency modeled by the ratio of morphometric variables and the increase/increment in diameter can explain the pine cones production in individual araucaria trees.

According to Costa et al. (2017) because of the importance of having adequate information to guide the silviculture to be conducted in mixed and unequal forests, crown efficiency studies make it possible to define which trees grow more in relation to the same area of horizontal projection of crown.

The hypotheses of the study are: (1) there is a relation between higher crown efficiency and increase crown area; (2) the number of pine cones tree ${ }^{-1}$ influences with the growth variables, ontogeny, size and shape; and (3) crown efficiency indicates need for silvicultural treatments. In this sense, the present study evaluate crown efficiency of Araucaria angustifolia as a function of the number of pine cones $\cdot$ tree $^{-1}$, annual periodic increment in diameter and morphometric variables in different forest sites in south Brazil, with the purpose of explaining their production and assisting with proposition for better efficiency and production of pine cones.

\section{Material and Methods}

\subsection{Characterization of the Study Area}

The data were measured in three forest sites with remnants of mixed ombrophilous forest, and natural occurrence of Araucaria angustifolia, located in south Brazil. Sites are located in the municipalities of Lages (LAG), Bom Jardim da Serra (BJS) and Painel (PNL) (Figure 1). The LAG site has a total area of 84 ha, BJS 73.46 ha and PNL 50.47 ha. Ninety-nine female trees were measured in LAG, 42 in BJS and 66 in PNL, totaling 207 trees sample.

The climate of the three sites is $\mathrm{Cfb}$ temperate, according to Köppen classification, characterized by being constantly wet without a dry season. In BJS, the altitude is $1,166 \mathrm{~m}$, average annual temperature of $14{ }^{\circ} \mathrm{C}$ and annual precipitation $1,740 \mathrm{~mm}$, in LAG the altitude is $1,200 \mathrm{~m}, 13.7^{\circ} \mathrm{C}$ average annual temperature and precipitation $1,722 \mathrm{~mm}$; and PNL altitude is $1,123 \mathrm{~m}, 15.3{ }^{\circ} \mathrm{C}$ average annual temperature and $1,543 \mathrm{~mm}$ annual precipitation (Alvarez et al., 2013). 

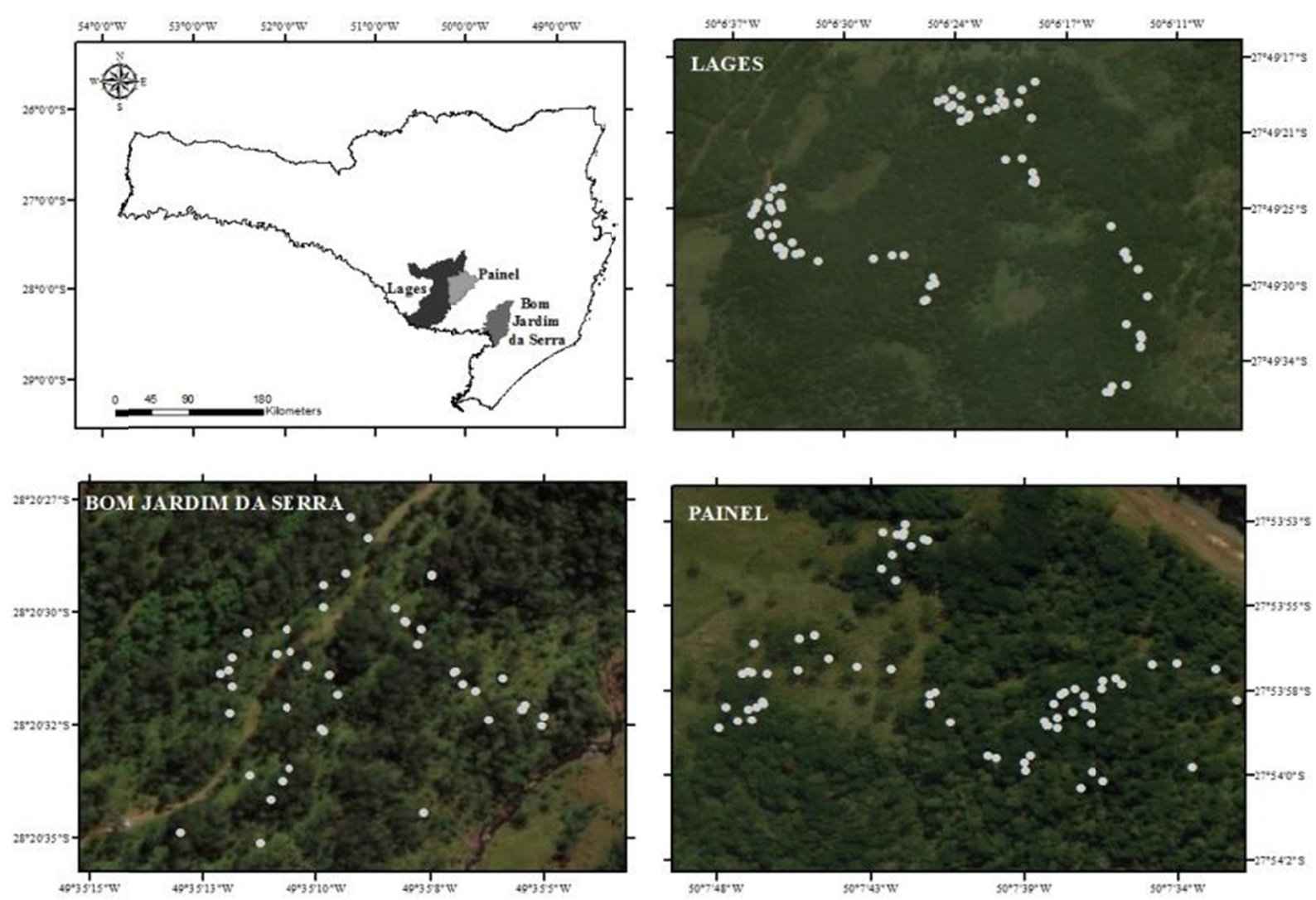

Figure 1. Map with the location and coordinates of Araucaria angustifolia trees samples in the study sites, south Brazil

\subsection{Morphometric, Dendrometric Measurements, Increment and Number of Pine Cones}

Female araucaria trees in their reproductive stage were sampled using an approach based on individual trees. From the selected samples, the number of pine cones in each tree was quantified, an also the proportion between female and male trees by counting under a $30 \mathrm{~m}$ line (measuring tape) distributed randomly at each study site.

Tree were tagged with their respective number and georeferenced using Garmin ${ }^{\circledR}$ GPS (Global Positioning System). Each tree was considered as a sample unit (SU). The descriptive statistics for dendrometric, morphometric and pine cones number variables are presented in Table 2.

For each tree, the diameter at breast height (d), total height (h), crown insertion height (cih), and four crown radii (rc) were measured in the north, south, east and west directions, with the aid of compass and Trupulese hypsometer. Two increment rolls were also removed at (d) height, and the number of pine cones tree ${ }^{-1}$ (np) was quantified. The data of crown length (cl), crown ratio (cr), horizontal projection area of the crown (hpac) and annual periodic increment in diameter $\left(\mathrm{API}_{\mathrm{d}}\right)$ for a period of ten years were calculated, according to the following equations:

$$
\begin{gathered}
\mathrm{cl}=\mathrm{h}-\mathrm{cih} \\
\mathrm{hpac}=\pi \cdot \overline{\mathrm{rc}}^{2} \\
\mathrm{cr}=\mathrm{c} / \mathrm{h} \times 100 \\
\operatorname{API}_{\mathrm{d}}=\left(\mathrm{d}-\mathrm{d}_{\mathrm{t}}\right) / \mathrm{t}
\end{gathered}
$$

Where, cl: crown length $(\mathrm{m})$; h: total tree height $(\mathrm{m})$; cih: crown insertion height (m); hpac: horizontal projection area of the crown $\left(\mathrm{m}^{2}\right)$; cr: crown ratio (\%); $\mathrm{API}_{\mathrm{d}}$ : annual periodic increment in diameter $\left(\mathrm{cm}\right.$ year $\left.{ }^{-1}\right)$; d: diameter at breast height obtained at the end of the period $(\mathrm{cm})$; $\mathrm{d}_{\mathrm{t}}$ : diameter at breast height obtained at the beginning of the period $(\mathrm{cm})$; t: period of time considered.

The counting of the number of pine cones tree $^{-1}$ was carried out in every area of crown coverage and in each sample area at different sites with the aid of binoculars, and pine cones were quantified for a period of two years 
during the months of March and April, 2017 and 2018. These are the months when pine cones are in pre-maturation stage and its collection has not yet been performed.

The increment rolls were removed using the Pressler sounder only in LAG, because for this site there was already study on the increment of the species (allowing testing and evaluating the efficiency of the crown with this variable). They were fixed on wooden supports, dried, sanded, and growth rings were marked. The width of the rings was measured using the Lintab 6 device, with an accuracy of $0.001 \mathrm{~mm}$. The measurements obtained were recorded in the Time Series Analysis Program -TSAP-Win with cross-dating.

\subsection{Crown Efficiency}

The crown efficiency ratio was calculated between the annual periodic increment in diameter $\left(\mathrm{API}_{\mathrm{d}}\right)$ and the horizontal projection area of the crown (Equation 5) for LAG (because in this site was carried out a previous study on the increase in diameter for the species), and the ratio between the number of pine cones tree ${ }^{-1}$ and the horizontal projection area of the crown (Equation 6) for the rest.

$$
\begin{gathered}
\mathrm{CE}_{1}=\mathrm{API}_{\mathrm{d}} / \mathrm{hpac} \\
\mathrm{CE}_{2}=\mathrm{np} / \mathrm{hpac}
\end{gathered}
$$

Where, CE: crown efficiency; API $_{d}$ : annual periodic increment in diameter in $\mathrm{cm}$.year ${ }^{-1}$; np: number of pine cones tree $^{-1}$; hpac: horizontal projection area of the crown $\left(\mathrm{m}^{2}\right)$.

In order to describe the relationship between crown efficiency (CE) and morphometric variables, annual periodic increment in diameter and number of pine cones $\cdot \operatorname{tree}^{-1}$, the adjustments were made to generalized linear models (GLM) regression (Table 1).

Table 1. Adjustment of generalized linear models to crown efficiency of individual araucaria trees according morphometric variables, annual periodic increment in diameter and number of pine cones

\begin{tabular}{lll}
\hline Crown efficiency ratio & Fitted models & Equation number \\
\hline & $\mathrm{CE}=\mathrm{b}_{0}+\mathrm{b}_{1} \cdot \mathrm{np}$ & $(7)$ \\
$\mathrm{CE}_{1}=\mathrm{API}_{\mathrm{d}} / \mathrm{hpac}\left(\mathrm{cm} / \mathrm{year} / \mathrm{m}^{2}\right)$ & $\mathrm{CE}=\mathrm{b}_{0}+\mathrm{b}_{1} \cdot \mathrm{API}_{\mathrm{d}}$ & $(8)$ \\
& $\mathrm{np}=\mathrm{b}_{0}+\mathrm{b}_{1} \cdot \mathrm{API}_{\mathrm{d}}$ & $(9)$ \\
$\mathrm{np}=\mathrm{b}_{0}+\mathrm{b}_{1} \cdot \mathrm{d}$ & $(10)$ \\
$\mathrm{CE}=\mathrm{b}_{0}+\mathrm{b}_{1} \cdot \mathrm{hpac}$ & $\mathrm{CE}=\mathrm{b}_{0}+\mathrm{b}_{1} \cdot \mathrm{cr}$ \\
$\mathrm{CE}_{2}=\mathrm{np} / \mathrm{hpac}\left(\right.$ pine $\left./ \mathrm{m}^{2}\right)$ & $\mathrm{CE}=\mathrm{b}_{0}+\mathrm{b}_{1} \cdot \mathrm{cl}$ & $(12)$ \\
& &
\end{tabular}

Note. CE: crown efficiency; $\mathrm{API}_{\mathrm{d}}$ : annual periodic increment in diameter in $\mathrm{cm}$; hpac: horizontal projection area of the crown in $\mathrm{m}^{2}$; np: number of pine cones tree ${ }^{-1}$; cl: crown length in $\mathrm{m}$; cr: crown ratio in $\%$.

\subsection{Data Analysis}

The model adjustments were processed with the Statistic Analysis System Software (SAS), version 9.4 using the PROC GENMOD procedure for generalized linear regression models. In order to verify the accuracy of the equations, we analyzed the statistics of deviance, Akaike's information criterion and graphical analysis of the observed and estimated data.

\section{Results}

For 2017, the number of pine cones counted was 633 for the three sites. This represents an average of 3.05 pine cones $\cdot \mathrm{tre}^{-1}$. For 2018,917 pine cones were counted, at an average of 4.42 pine cones $\cdot$ tree ${ }^{-1}$, totaling 1,550 pine cones in these two consecutive years. The proportion of males was $70 \%$ and females $30 \%$ for all sites.

The descriptive statistics of the dendrometric, morphometric, number of pine cones, annual periodic increment in diameter, and crown efficiency variables are presented in Table 2. In terms of average number of pine cones, Silva and Reis (2009) found in the Caçador Forest Genetic Reserve an average of 5.6 pine cones tree ${ }^{-1}$ in 2006. 
Table 2. Descriptive statistics of dendrometric, morphometric, number of pine cones and annual periodic increment in diameter variables for Araucaria angustifolia in the three study sites, south Brazil

\begin{tabular}{|c|c|c|c|c|c|}
\hline Variable & Site & Mean & Minimum & Maximum & CV $(\%)$ \\
\hline \multirow{3}{*}{$\mathrm{np}$} & LAG & 7.9 & 1 & 28 & 60.35 \\
\hline & BJS & 3.5 & 1 & 13 & 45.39 \\
\hline & PNL & 8.5 & 1 & 24 & 69.81 \\
\hline \multirow{3}{*}{$\mathrm{d}(\mathrm{cm})$} & LAG & 47.4 & 22.7 & 100.2 & 31.40 \\
\hline & BJS & 31.8 & 14.3 & 50.9 & 25.66 \\
\hline & PNL & 51.3 & 20.3 & 88.1 & 27.65 \\
\hline \multirow{3}{*}{$\mathrm{h}(\mathrm{m})$} & LAG & 19.5 & 10.5 & 30.7 & 21.25 \\
\hline & BJS & 17.4 & 9.2 & 31.0 & 29.39 \\
\hline & PNL & 16.3 & 8.8 & 27.7 & 21.28 \\
\hline \multirow{3}{*}{$\operatorname{cl}(\mathrm{m})$} & $\mathrm{LAG}$ & 7.4 & 3.0 & 16.6 & 34.23 \\
\hline & BJS & 3.4 & 0.3 & 12.9 & 87.88 \\
\hline & PNL & 4.9 & 0.2 & 11.0 & 56.92 \\
\hline \multirow{3}{*}{$\mathrm{hpac}\left(\mathrm{m}^{2}\right)$} & $\mathrm{LAG}$ & 56.7 & 9.3 & 148.4 & 54.75 \\
\hline & BJS & 36.4 & 8.2 & 108.4 & 63.64 \\
\hline & PNL & 78.5 & 7.3 & 314.1 & 65.61 \\
\hline \multirow{3}{*}{$\operatorname{cr}(\%)$} & $\mathrm{LAG}$ & 39.4 & 14.2 & 75.2 & 34.24 \\
\hline & BJS & 19.4 & 1.9 & 53.3 & 69.99 \\
\hline & PNL & 29.4 & 1.6 & 75.5 & 51.78 \\
\hline $\mathrm{API}_{\mathrm{d}}\left(\mathrm{cm} . \mathrm{year}^{-1}\right)$ & LAG & 0.3916 & 0.1273 & 0.5904 & 24.94 \\
\hline \multirow[t]{2}{*}{$\mathrm{CE}_{1}$} & $\mathrm{LAG}$ & 0.0091 & 0.0020 & 0.0423 & 67.28 \\
\hline & LAG & 0.2421 & 0.0259 & 0.8739 & 75.28 \\
\hline \multirow[t]{2}{*}{$\mathrm{CE}_{2}$} & BJS & 0.1322 & 0.0102 & 0.4105 & 85.03 \\
\hline & PNL & 0.1521 & 0.0117 & 1.0949 & 91.68 \\
\hline
\end{tabular}

Note. np: number of pine cones $\cdot \operatorname{tre}^{-1}$ for the years 2017 and 2018; cl: crown length in m; hpac: horizontal projection area of the crown in $\mathrm{m}^{2}$; cr: crown ratio in \%; $\mathrm{API}_{\mathrm{d}}=$ annual periodical increment in diameter in $\mathrm{cm}$ year $^{-1}$; CE: crown efficiency.

The results show that LAG and PNL presented higher average number of pine cones tree ${ }^{-1}$, higher crown efficiency and higher mean of morphometric variables. This demonstrates higher pine cone.tree ${ }^{-1}$ yield and efficiency have high correlation with better growth conditions and increase in tree crown dimensions. Repetitions in pine cone production are necessary to verify this result. However, the two years of study allowed this evaluation, because the worst results in all variables (production, dendrometric and morphometric) were for BJS (Figure 2A). 

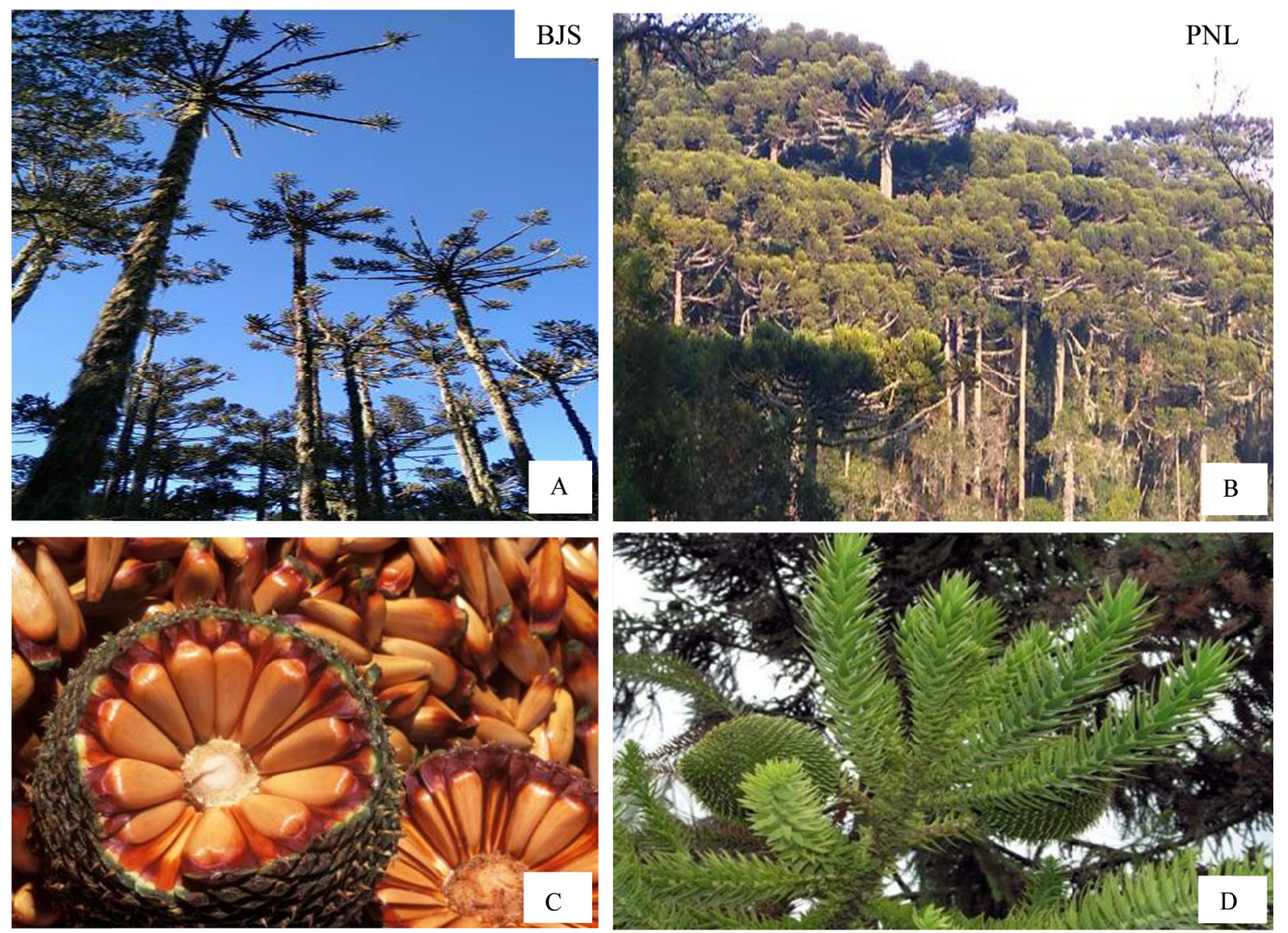

Figure 2. The different dendro/morphometric conditions, ontogeny, pine cones production, crown formation, size, site and edible seeds in the study area: (A): Bom Jardim da Serra (BJS); (B) Painel; (C): Pine cones with edible seeds; (D): Formation and location of the pine cones in the crown. Source: (A) and (B) Author, (C) and (D) https://produto.mercadolivre.com.br/MLB-993620769-5-mudas-de-pinheiro-araucaria-pinho-pinha-_JM

Pine cones production is related to lateral crown growth space, as well as site density and competition. According to Costa et al. (2017) the availability of water, light, competition among trees, site conditions, among other factors, are those that limit tree growth. Therefore, we can say they influence production, be it wood or non-timber resources (pine cones and edible seeds).

We can indicate that the $\mathrm{API}_{\mathrm{d}}$ presents an inferior value to the capacity of species growth. This lower value indicates some interesting characteristics, such as stagnation of growth, competition, old-growth trees and a smaller amount of pine cones. The study revealed the greatest number of pine cones was found in trees that reached the upper canopy or were on the edge of the forest.

Female trees in competition or in the interior of the forest as well as very old trees presented smaller amount of pine cones, only one. This feature is related to density, lateral space for growth and increase in crown size, as well as the dispersal characteristic of pollen (by wind), which can make it difficult to reach female trees inside the forest.

The $\mathrm{CE}_{1}$ presents a value less than zero, evidencing that the larger the area of horizontal projection of the crown less the efficiency of the crown. The equation shows that these variables have an inversely proportional relation. Thus, for a same increment value the efficiency will be lower the higher the hpac.

The values of $\mathrm{CE}_{2}$ indicate that the LAG and PNL have more efficient crowns and higher average number of pine cones $\cdot$ tree $^{-1}$. The values of $\mathrm{CE}_{2}$ indicate that for the same amount of pine cones tree ${ }^{-1}$, the higher the hpac the lower the efficiency of the crown. Thus, trees with higher value of $\mathrm{CE}_{2}$ have better physiological capacity for pine production. As the ratio is pine cone.tree $\mathrm{e}^{-1} / \mathrm{hpac}\left(\mathrm{m}^{2}\right)$ it expresses the amount occupied by each pine cone in the crown, for example, 10 pine cones $\cdot \operatorname{tree}^{-1} / 10 \mathrm{~m}^{2}$ shows that a pine cone occupies $1 \mathrm{~m}^{2}$ of the crown.

According to Solórzano-Filho (2001), the number of pine cones tree ${ }^{-1}$ is dependent on the size of the crown. Crown size is dependent on density, vertical and horizontal space and growth resources. Thus, the results allow 
associating lower pine cones production to a need for silvicultural intervention, or management regimes that aim to produce adequate pine cones and edible seeds.

Pine cones production is associated with crown efficiency, tree growth and morphometry (Figures 2 and 3). However, it is worth mentioning this is a dioecious species which depends on the dispersion of the pollen by the wind for fertilization and formation of the pine cones and edible seeds. Thus, even with well-shaped and more efficient trees, production will depend on the seasonality and characteristics of the environment conducive to pine cones formation.

According to Wendling and Zanette (2017), pollination is more effective in dry weather. With intense rainy seasons the production of edible seeds after two years will be low. According to the same authors, in natural araucaria populations productivity is low due to the lower number of branches kept in the shaded plants and the lower density of productive female plants (15 to 20 plants.ha $\left.^{-1}\right)$. Araucaria trees growing in the open environment generally produce more pine cones.

The crown efficiency equations $(7,8,11,12$ and 13) obtained lower value of deviance (Table 3). Models included the variables $\mathrm{np}, \mathrm{API}_{\mathrm{d}}$, hpac, cr, and cl obtained the best adjustments due to higher correlation between variables. Costa et al. (2017) studied the efficiency of the araucaria crown verified inclusion of cl improved the fit of the equations.

More efficient trees are those show better sociological position and greater measure of crown variables. The results show reduction of efficiency with increase of hpac. These results refer to the behavior in terms of crown plasticity and variability of growth rate. The knowledge of the efficiency of a tree is essential for the establishment of a structured forest that increase the efficiency of use of tree resources and the production at the level of stands (Gspaltl et al., 2013).

Table 3. Equations for crown efficiency and their statistical adjustment criteria in the study area, south Brazil

\begin{tabular}{|c|c|c|c|c|c|}
\hline Equation & $\mathrm{b}_{0}$ & $b_{1}$ & $\mathrm{D}$ & AIC & LF \\
\hline \multicolumn{6}{|l|}{$L A G$} \\
\hline 7 & 0.0117 & -0.0003 & 29.2 & -792.2 & $G-\mu$ \\
\hline 8 & 0.022 & 0.0177 & 29.7 & -790.6 & $G-\mu$ \\
\hline 9 & 7.1079 & 3.5472 & 41.5 & 105.4 & $G-\mu$ \\
\hline 10 & 1.1233 & 0.0187 & 93.2 & 1168.1 & $G-\ln (\mu)$ \\
\hline 11 & -1.233 & -0.0094 & 38.6 & -188.9 & $G-\ln (\mu)$ \\
\hline 12 & -1.8663 & 0.0036 & 47.3 & -167.4 & $G-\ln (\mu)$ \\
\hline 13 & 0.1871 & -0.0012 & 47.5 & -166.4 & $G-\mu$ \\
\hline \multicolumn{6}{|l|}{$B J S$} \\
\hline 11 & -1.2335 & -0.0257 & 15.4 & -112.0 & $G-\ln (\mu)$ \\
\hline 12 & -1.9704 & -0.0028 & 27.7 & -85.7 & $G-\ln (\mu)$ \\
\hline 13 & -1.9276 & -0.0293 & 27.4 & -86.2 & $G-\ln (\mu)$ \\
\hline \multicolumn{6}{|l|}{$P N L$} \\
\hline 11 & -1.2786 & -0.0093 & 32.9 & -145.0 & $G-\ln (\mu)$ \\
\hline 12 & -1.8645 & -0.0006 & 49.1 & -116.25 & $G-\ln (\mu)$ \\
\hline 13 & -1.832 & -0.0104 & 49.0 & -116.3 & $G-\ln (\mu)$ \\
\hline
\end{tabular}

Note. D: deviance; AIC: Akaike's information criterion; LF $(G-\mu)$ : identity link function, gamma distribution; $G-\ln (\mu)$ : logarithmic link function, gamma distribution.

The graphical results of the model adjustments for $\mathrm{CE}_{1}$ and $\mathrm{CE}_{2}$ (Figures 3 and 4) show accuracy of the models without discrepant values. Points farthest from the line of adjustment indicate the smaller capacity to explain the variability of the fit. However, they are of interest due to ontogeny, variability and dynamics of crown changes, pine cones production, size and allometry of trees in mixed forests.

The results show that the lower crown efficiency, lower number of pine cones, and higher efficiency, greater annual periodical increment in diameter. Thus, it is observed pine cones production is related to the physiological vigor and tree growth, as well as the sociological position and the efficiency to use the light. 
Figure 3 also shows the greater annual periodicals increment in diameter and diameter at breast height, and the greater production of pine cones. However, the increase of np with $\mathrm{d}$ is concentrated in trees of 30 to $60 \mathrm{~cm}$ of diameter, and the increase in diameter will result in a smaller number of pine trees and lower tree efficiency. Thus, the favored increase in production consists of managing the forest with removal of larger trees. This shows that for most variables, increment and pine cones production as well as the physiological trees age are important. Old trees have reduced growth, efficiency and production.
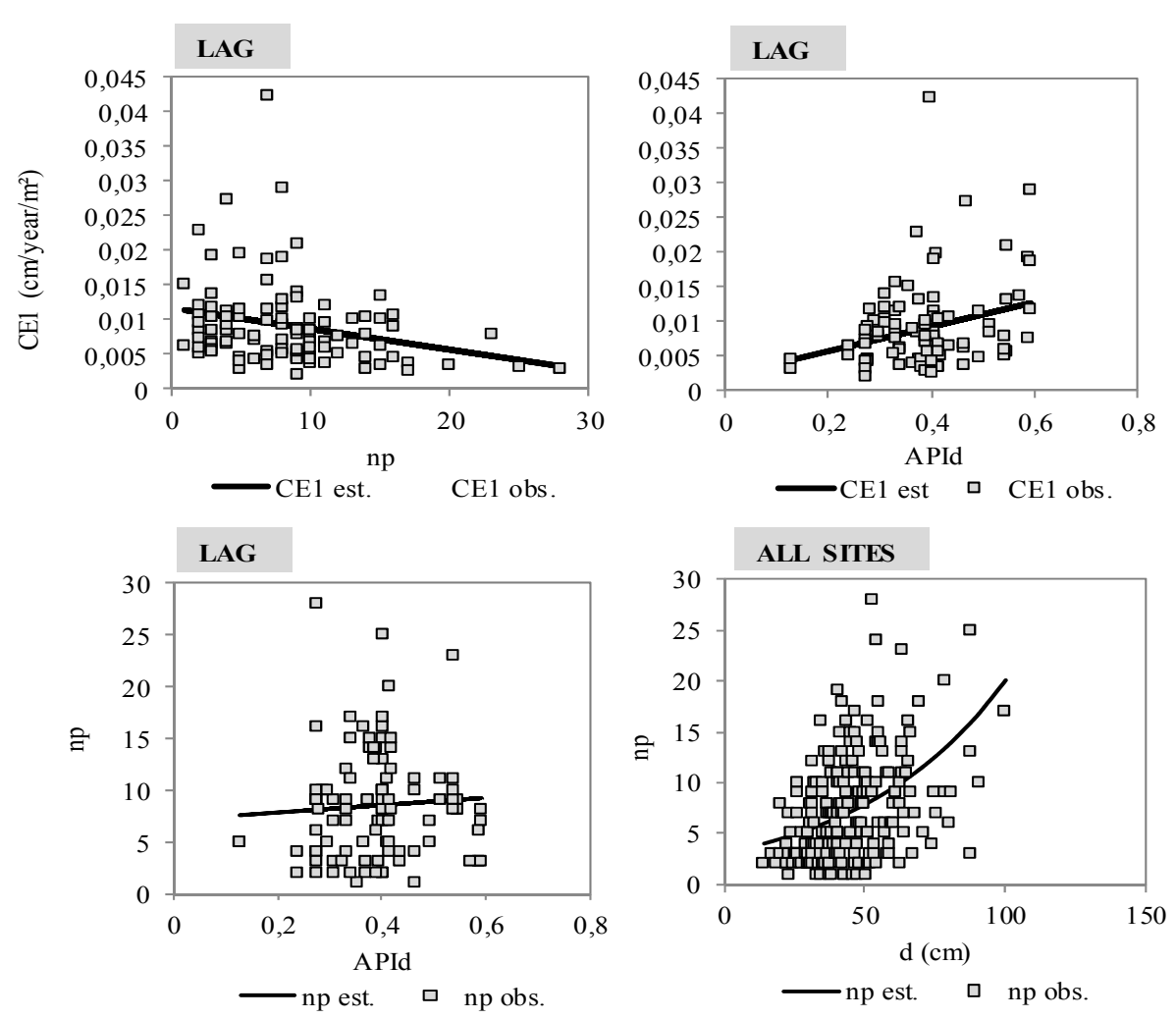

Figure 3. Accuracy of the adjusted models for Brazilian pine trees for the relationship between crown efficiency $\left(\mathrm{CE}_{1}\right)$ according of the number of pine cones $\cdot \operatorname{tree}^{-1}(\mathrm{np})$ and annual periodical increment in diameter $\left(\mathrm{API}_{\mathrm{d}}\right)$ and number of pine cones tree $^{-1}(\mathrm{np})$ according of the annual periodical increment in diameter $\left(\mathrm{API}_{\mathrm{d}}\right)$ for Lages site and diameter at breast height (d) for all sites. LAG: Lages; CE1 est.: estimated crown efficiency; CE1 obs.: observed crown efficiency; np est.: estimated number of pine cones tree $^{-1}$; np obs.: observed number of pine cones $\cdot \operatorname{tree}^{-1}$

The results of the adjustment for $\mathrm{CE}_{2}$ (Figure 4) show a higher hpac decreases the efficiency of the crown. This is because a higher hpac, greater age of the tree and lower efficiency and pine cones production. That is, trees present a period of productivity, indicating silvicultural treatments are important for production, because older trees have their production decreased and younger trees need space of growth.

The efficiency regarding the variables cr and cl shows the higher value of these variables, the lower efficiency of the crown, because higher values of $\mathrm{cr}$ and $\mathrm{cl}$ occur in younger trees or in trees that are growing free, not yet in the stage of pine cones production, which occurs between 15 and 18 years of age. 

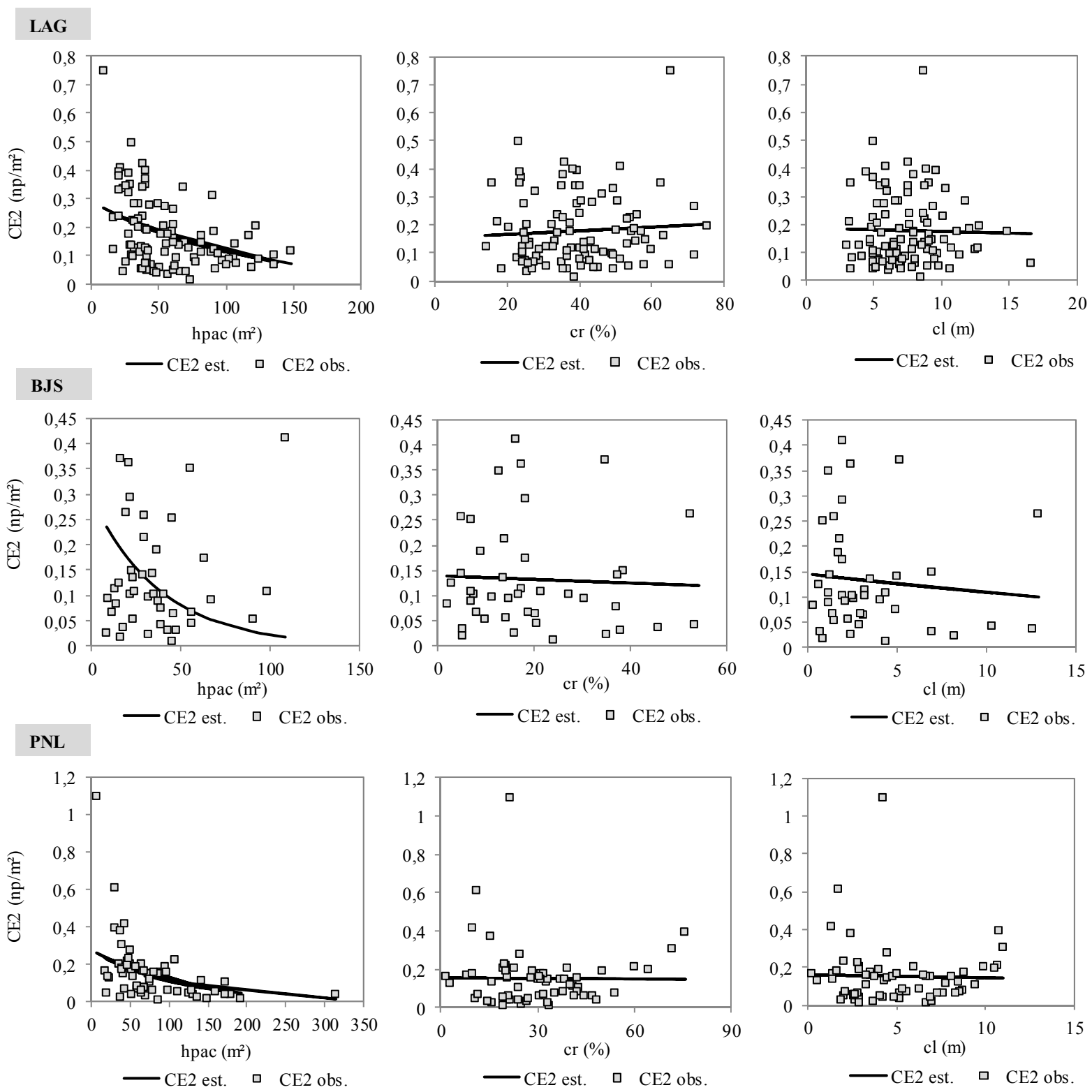

Figure 4. Accuracy of the adjustment of the relationship between crown efficiency $\left(\mathrm{CE}_{2}\right)$ according to dendro/morphometric variables and pine cones $\cdot$ tree $^{-1}$ production behavior with tree shape and dimension variables for Brazilian pine at the three study sites, south Brazil. LAG: Lages; BJS: Bom Jardim da Serra; PNL: Painel; np: number of pine cones tree ${ }^{-1}$; $\operatorname{cr}(\%)$ crown ratio; $\mathrm{cl}(\mathrm{m})$ : crown length in $\mathrm{m}$; CE2 est.: estimated crown efficiency; CE2 obs.: observed crown efficiency

\section{Discussion}

Adjustments of crown efficiency and its accuracy are related to the wide variability of crown morphology and expansion according to the forest density. According to Pretzsch et al. (2017), this variability can be demonstrated by calculating the crown radius expected for trees of the same diameter. The crown radius refers to the maximum crown expansion that is relevant for intervention planning in the forest, as it indicates its growth.

Thus, in terms of efficiency and number of pine cones there will be differences in relation to free growing trees and trees develop on average, minimal or strong restriction of lateral space. What is of interest in forest management is to predict the required space for trees in dense forests and planting plans with the species.

Crown efficiency and size determine tree growth, carbon sequestration, shading, number of pine cones, and wind break risk, among others. The dependence of crown size on species, resource supply and age of trees complicates 
an accurate assessment of the need for space of a tree, functions and services depending on its size in forest areas (Pretzsch et al., 2017).

However, in terms of araucaria management, there is a need for planning both for wood and pine cones production (complementary incomes), in order to help define the ideal spacing and prognosis of future forest structure and continuous production.

A lower average number of pine cones tree ${ }^{-1}$ are related to a lower number of female trees, as well as to forest density. So much that more productive trees were those either on the edge of the forest or growing free. Thus, silvicultural treatments may help increase the average spacing between trees and pine cones production.

A planned intervention contributes to the increase of variables such as crown radius, crown length and crown ratio, as well as increment rate, and consequently pine cones production. The increase of these variables is of extreme importance, since the location of pine cones occurs mostly in the extremity of branches. As efficiency decreases with increasing hpac, removing larger trees would be the specific recommendation for pine cones production. Meaning trees of higher hpac have physiologically lost their productive capacity and there is a limit of size of crown area and productive efficiency.

Binkley et al. (2013), comment that the production of components of a tree or forest depends on the absorption of light and the efficiency of light conversion. Larger trees tend to absorb more light and use more efficiently for their production; the greater growth of large trees usually results from a combination of light absorption and increased light efficiency, which makes the forests more productive and influenced by the species composition, site and silvicultural treatments.

The evidence of the relationship between crown efficiency and pine cones production rationally shows the need for silvicultural interventions, since crown growth and expansion, sociological position, forest density and tree age are factors that alter many aspects of the structure and production of forests.

Interventions are important because within a species, differences crown efficiency should be explainable in terms of capture and utilization of growth limiting resources by individual trees, along with overall stand dynamics (Reid et al., 2004). Trees growing under conditions of high competition usually showed a smaller crown cross-sectional area, shorter crown depth, greater height and lower taper for a given diameter (Del Rio et al., 2018).

Thus, variability in pine cones production can be influenced by ontogeny, competition and environmental conditions, tree position in forest structure, crown size and height, as well as interception of light and growth. These factors are important because trees growing in high density tend to respond negatively to growth in crown diameter and increase in height, interfering in the production of pine cones.

Relative height is also one of the strongest predictors of crown length for many European species (Forrester et al., 2017). While canopy stratification is notoriously difficult to quantify (Parker \& Brown, 2000), the relative height variable is useful for quantifying how the vertical position of trees within a canopy determines their crown architecture. During the growth and development of trees in a stand, intense competition for light, nutrients and growth space can induce mortality; this process is known as dense-dependent, mortality or self-thinning (Quinonez-Barraza et al., 2018).

In a direct way, the increase of pine cones production occurs with increased morphometric and increment variables, proportionally indicating the need for growth space, leaf area increase, crown efficiency, growth efficiency and better pine cones production, making clear the need for density planning and competition for the management of pine cones forest production.

Trees overcame past competition and reached the stratum of co-dominant and dominant have larger crown and greater number of pine cones. It evidences that the growth in height and the allometric component of trees are decisive factors for its shape and production. This is due to the fact trees in mixed forests with high density grow first in height, seeking space of growth for the crown growth and consequently increase its efficiency.

Thus, the initial stages of establishment and development are keys in the life cycle of tree species, where plant attributes are essential factors for the maintenance and survival of their populations (Escudero et al., 2017). During this period, the ontogenetic changes in the crown assume great importance, together with leaf arrangement, dimension and the resulting effects of crown efficiency in light capture, growth, and the subsequent pine cones production. Crown architecture determines the pattern of light interception and is a key factor influencing the performance of tree species (Escudero et al., 2017). 
An increase in tree leaf area is accompanied by a gain in relative height and hence by improved light conditions. For individual tree crowns, greater availability of light generally results in a greater net photosynthetic rate and greater tree growth (Maguire et al., 1998).

Growth rates of trees are driven by factors influence the amount of resources captured and the efficiency of resource use. The amount of light captured and the efficiency of light use strongly depend on crown characteristics and leaf traits (Li et al., 2017).

The results for the hypotheses tested show that the increase in hpac decreases the crown efficiency. The np has a direct influence with the variables of the increment in diameter and increase in size in diameter and shape of the crown, until the physiological age stabilizes the increase of these variables, as well as indicates the need for silvicultural treatments for the continuity of the pine cones production and edible seeds.

\section{Conclusions}

The results of the study allow concluding that the number of pine cones tree $e^{-1}$ differs according to the site, ontogeny, forest density, tree location (on the edge or interior of the forest) and tree crown dimension. The adjustments of the models showed precision and explained the variation of crown efficiency, indicating for all sites that the increase in crown size decreases its efficiency and this is correlated with pine cones production.

The crown efficiency equations show that as the horizontal projection of crown area increases, pine cones yield and crown efficiency decrease. While the number of pine cones tree ${ }^{-1}$ increases with the annual periodical increment in diameter and diameter. However, it is not a linear increasing, but with a tendency to stabilize with the increase in size and growth (there is a limit in size that the production of pine cones $\cdot$ tree $^{-1}$ decreased).

We can conclude that silvicultural treatments are necessary and when carried out should aim at the trees with greater horizontal projection of crown area. However, in order to intervene it is necessary to change the forest legislation, because non-management since its implementation has brought more damage than benefits to the forest ecosystem, society and production, in this case of pine cones and their edible seeds.

\section{Acknowledgements}

The authors are grateful for the support of the Santa Catarina State University, Department of Forest Engineering and its Graduate Program. The FAPESC (Foundation for Research Support of the Santa Catarina State)-case number 2017TR639-financial assistance for research groups and the owners of the Araucaria Forest for the availability of this study.

\section{References}

Alvares, C. A., Stape, J. L., Sentelhas, P. C., Gonçalves, J. L. M., \& Sparovek, G. (2013). Köppen's climate classification map for Brazil. Meteorologische Zeitschrift, 22(6), 711-728. https://doi.org/10.1127/09412948/2013/0507

Assman, E. (1961). Waldertargskunde (p. 490). Müchen: Bayr. Landw.

Assmann, E. (1970). The principles of forest yield study (p. 506). Oxford: Pergamon Press. https://doi.org/ 10.1016/B978-0-08-006658-5.50007-8

Beckert, S. M., Rosot, M. A. D., \& Rosot, N. C. (2014). Crescimento e dinâmica de Araucaria angustifolia (Bert.) O. Ktze. em fragmento de Floresta Ombrófila Mista. Scientia Forestalis, 42(102), 209-218.

Binkley, D., Campoe, O. C., Gspaltl, M., \& Forrester, D. I. (2013). Light absorption and use efficiency in forests: why differ for trees and stands. Forest Ecology and Management, 288, 5-13. https://doi.org/10.1016/ j.foreco.2011.11.002

Burger, H. (1939). Baumkrone und zuwachs in zwei hiebsreifen fichtenbeständen. Mitteilungen der Schweizerischen Anstalt für das Forstliche Versuchswesen, 21, 147-176.

Costa, E. A., Finger, C. A. G., Schneider, P. R., Hess. A. F. (2017). The crown efficiency of Parana-Pine. Australian Journal of Basic and Applied Sciences, 11(3), 86-92. https://doi.org/10.22587/ajbas.2017.11.13.9

Costa, E. A., Hess, A. F., Klein, D. R., \& Finger, C. A. G. (2018). Height-diameter models for Araucaria angustifolia (Bertol.) Kuntze in natural forests. Journal of Agricultural Science, 10(8), 132-145. https://doi.org/10.5539/jas.v10n8p133

Del Río, M., Pretzsch, H., Ruíz-Peinado, R., Ampoorter, E., Annighöfer, P., Barbeito, I., \& Bravo-Oviedo, A. (2018). Species interactions increase the temporal stability of community productivity in Pinus 
sylvestris-Fagus sylvatica mixtures across Europe. Journal of Ecology, 105, 1032-1043. https:/doi.org/ $10.1111 / 1365-2745.12727$

Escudero, A., del Río, T., Zulueta, P. S., \& Mediavilla, S. (2017). Ontogenetic changes in Crown architecture and leaf arrangement: Effects on light capture efficiency in three species differing in leaf longevity. Ecological Research, 32, 595-602. https://doi.org/10.1007/s11284-017-1470-3

Forrester, D. I. (2013). The spatial and temporal dynamics of species interactions in mixed-species forests: From pattern to process. Forest Ecology and Management, 312, 282-292. https://doi.org/10.1016/j.foreco. 2013.10.003

Forrester, D. I., Benneter, A., Bouriaud, O., \& Bauhus, J. (2017). Diversity and competition influence tree Allometry-Developing allometric functions for mixed-species forests. Journal of Ecology, 105, 761-774. https://doi.org/10.1111/1365-2745.12704

Gspaltl, M., Sterba, H., \& O’Hara, K. L. (2012). The relationship between available area efficiency and area exploitation index in an even-aged coast redwood (Sequoia sempervirens) stand. Forestry, 85, 567-577. https://doi.org/10.1093/forestry/cps052

Hess, A. H., Silveira, A. C. da, Krefta, S. M., Santos, D. V. dos, Filho, M. D. H. V., Atanazio, K. A., ... Liesenberg, V. (2018). Crown dynamics of Brazilian pine (Araucaria angustifolia) in Santa Catarina region of Brazil. Australian Journal of Crop Science, 12(03), 449-457. https://doi.org/10.21475/ajcs.18.12. 03pne928

Li, Y., Kröber, W., Bruelheide, H., Härdtle, W., \& Oheimb, G. von. (2017). Crown and leaf traits as predictors of subtropical tree sapling growth rates. Plant Ecology, 10(1), 136-145. https://doi.org/10.1093/jpe/rtw041

Maguire, D. A., Brissette, J. C., \& Gu, L. (1998). Crown structure and growth efficiency of red spruce in uneven-aged, mixed-species stands in Maine. Canadian Journal for Forest Research, 28, 1233-1240. https://doi.org/10.1139/x98-093

O'Hara, K. L. (1988). Stand structure and growing space efficiency following thinning in an even-aged Douglas-fir stand. Canadian Journal for Forest Research, 18, 859-866. https://doi.org/10.1139/x88-132

Parker, G. G., Brown, M. J. (2000). Forestry canopy stratification-Is it useful? The American Naturalist, 155, 476-484. https://doi.org/10.2307/3078929

Pretzsch, H., Biber, P., Enno, U., Dahlhausen, J., Rötzer, T., Caldentey, J., Koike, T., ... Pauleit, S. (2015). Crown size and growing space requirement of common tree species in urban centres, parks, and forests. Urban Forestry \& Urban Greening, 14, 466-479. https://doi.org/10.1016/j.ufug.2015.04.006

Quinonez-Barraza, G., Tamarit-Urias, J. C., Martinez-Salvador, M., Garcia- Cuevas, X., de los Santos-Posadas, H. M., \& Santiago-Garcia, W. (2018). Maximum density and density management diagram for mixed-species forests in Durango, Mexico. Revista Chapingo Serie Ciencias Forestales y del Ambiente, 24(1), 73-90. https://doi.org/10.5154/r.rchscfa.2017.09.056

Reid, D. E. B., Lieffers, V. J., \& Silins, U. (2004). Growth and crown efficiency of height repressed lodgepole pine: are suppressed trees more efficient? Trees, 18, 390-398. https://doi.org/10.1007/s00468-003-0317-4

Sanquetta, C.R., Behling, A., Corte, A. P. D., Fernandes, A. C., Beckert, S. M., \& Simon, A. A. (2014). Equations for estimate of the crown diameter for the Black wattle. Revista Floresta e Ambiente, 21(2), 192-205. https://doi.org/10.4322/floram.2014.018

Silva, C. V. da., \& Reis, M. S. dos. (2009). Brazilian pine nuts' in Caçador region, SC: aspects of the attainment and its importance for local communities. Ciência Florestal, 19(4), 363-374.

Silveira, A. C. da, Hess, A. F., Schorr, L. P. B., Krefta, S. M., Santos, D. V. dos, Filho, M. D. H. V., ... Borsoi, G. A. (2018). Management of Brazilian pine (Araucaria angustifolia (Bertol) Kuntze) based on the Liocourt model in a mixed ombrophilous forest in Southern Brazil. Australian Journal of Crop Science, 12(02), 311-317. https://doi.org/10.21475/ajcs.18.12.02.pne927

Solórzano-Filho, J. A. (2001). Demografia, fenologia e ecologia da dispersão de sementes de Araucaria angustifolia (Bert.) Kuntze (Araucariaceae), numa população relictual em Campos do Jordão, SP (Master's Dissertation, University of São Paulo, Brazil).

Sterba, H., \& Amateis, R. L. (1998). Crown efficiency in a loblolly pine (Pinus taeda) spacing experiment. Canadian Journal for Forest Research, 28, 1344-1351. https://doi.org/10.1139/x98-115 
Sterba, H., Andrae, F., \& Pambudhi, F. (1993). Crown efficiency of oak standards as affected by mistletoe and coppice removal. Forest Ecology and Management, 62, 39-49. https://doi.org/10.1016/0378-1127(93) 90040-T

Wadsworth, F. H. (2000). Producción forestal para América Tropical (p. 602). Washington: USDA.

Waring, R. H., Newman, K., Bell, J. (1981). Efficiency of tree crowns and stemwood production at different canopy leaf densities. Forestry, 54, 129-137. https://doi.org/10.1093/forestry/54.2.129

Wendling, I., Zanette, F. (2017). Araucária: particularidades, propagação e manejo de plantios (p. 157). Embrapa, Brasília, DF.

\section{Copyrights}

Copyright for this article is retained by the author(s), with first publication rights granted to the journal.

This is an open-access article distributed under the terms and conditions of the Creative Commons Attribution license (http://creativecommons.org/licenses/by/4.0/). 